\title{
Role of C-reactive protein in rapid diagnosis of early neonatal sepsis in a tertiary care hospital
}

\author{
Devi D. ${ }^{1}$, Kumar R. ${ }^{2}$ \\ ${ }^{1}$ Dr Dipti Devi, Associate Professor of Pediatrics, Tezpur Medical College, Assam, ${ }^{2}$ Dr Rajesh Kumar, Silchar \\ Medical College, Assam, India.
}

Address for Correspondence: Dr Rajesh Kumar, Email: rajesh.kumar.amc1985@gmail.com

\begin{abstract}
Introduction: C-reactive protein (CRP) is a serum glycoprotein produced by the liver during acute inflammation. Because it disappears rapidly when inflammation subsides, its detection signifies the presence of a current inflammatory process. Serial measurements give information on the resolution or continuation of the inflammatory process. Recently, more sensitive immunoassay methods create a renewed interest of its utility in clinical practice. . Early diagnosis of neonatal sepsis is often difficult. A prospective, cohort study was done in hospital born newborns to find out utility of CRP for early diagnosis of early onset sepsis for a period of one year from July 2013 to June 2014 in a tertiary care hospital. Method: Serum CRP was measured by immunoturbidity method at birth, at 24 hours and at 48 hours of age of suspected sepsis. Results: Out of 298 babies, 15(5.03\%) were found with probable sepsis in presence of symptoms and/or positive sepsis screen. Blood culture was positive in $7(46.66 \%)$ cases of probable sepsis. Our study shows that elevated CRP $(>6 \mathrm{mg} / \mathrm{L})$ is associated with maternal risk factors, but not significantly correlated with culture proven EOS. It showed high sensitivity, low specificity, low positive predictive value and high negative predictive value as $93.3 \%, 44.9 \%, 8.2 \%$ and $99.2 \%$ respectively. When combined with other components of sepsis screen including ANC $<1500 /$ cu.mm, band cell $>0.2$ or TLC $<5000 /$ cu.mm, its specificity significantly increases. Conclusion: In combination with other sepsis screen, it can be used as an early diagnostic tool. Lower levels $(<6 \mathrm{mg} / \mathrm{l})$ are helpful in excluding sepsis.
\end{abstract}

Key words: Newborn, Early onset sepsis, C-reactive protein (CRP)

\section{Introduction}

The newborn is an immunocompromized host prone to sepsis. Globally out of 130 million babies born in a year, 4 million die within one month [1]. The current NMR in India is 25/1000 live births. It is almost stagnant in last few years. Neonatal sepsis is one of the commonest causes of neonatal mortality and morbidity specially in developing countries [2]. According to the National Neonatal Perinatal Database, it is 30/1000 live birth in India [3].

Early diagnosis and prompt initiation of appropriate antibiotic is the cornerstone of management. However clinical presentation is nonspecific and early diagnosis is difficult. Though blood culture is gold standard, it is costly, requires a well equipped laboratory, time consuming and success rate is $40 \%$ only. C- reactive protein (CRP) is a well-known indicator of inflammation. Recently improved, highly sensitive and standardized quantitative immunoassay in serum have allowed a re-evaluation of its potential as a diagnostic laboratory test.

The discovery of C-reactive protein was reported in 1930 by Tillet and Francis. Sera of patients suffering from acute infection precipitated with a non-protein pneumococcus extracts called $\mathrm{C}$ polysaccharide in the presence of calcium ions. The protein that caused this reaction was therefore called C- reactive protein [4]. Philipson [5] first described the presence of CRP in bacterial infection of neonates. Later Felix and Hanson [6] in 1981 observed that

Manuscript received: $14^{\text {th }}$ June 2016

Reviewed: $24^{\text {th }}$ June 2016

Author Corrected: $2^{\text {nd }}$ July 2016

Accepted for Publication: $9^{\text {th }}$ July 2016 
CRP increased invariably in neonatal infection and more consistently with septicemia and bacterial meningitis. The pentameter structure of CRP, including calcium and phosphor-choline binding sites allow CRP to recognize and bind to a variety of biologic substrates, including phosphocholine and phospholipid components of damaged cell walls and chromatin and nuclear antigens resulting in the formation of CRP-ligand complexes [8,9,10,11]. They also bind directly to neutrophils, macrophages and other phagocytes, stimulating an inflammatory response and the release of cytokines. The fetus is able to produce CRP and other acute-phase reactant proteins as early as 4 to5 weeks of gestation. Paired mother and infant sampling shows that CRP does not cross the placenta and although maternal risk factors can exert an effect on the fetus, there is no correlation between maternal and infant CRP levels at birth[12,13,14,15].CRP is the most sensitive of the acute-phase proteins with levels rising as much as 1,000 -fold during the acute inflammatory processes [11,16,17]. Levels begin to rise within 4 to 6 hrs of the onset of signs of infection or tissue injury and peak 24 to $48 \mathrm{hrs}$ later. They rapidly disappear as the inflammatory process resolves $[18,19,20]$. The degree of CRP response may be dependent on the amount of tissue damage present. For example, elevated CRP levels from 150 to $350 \mathrm{mg} / \mathrm{L}$ have been reported in cases of invasive bacterial meningitis, whereas smaller rises from 20 to $40 \mathrm{mg} / \mathrm{L}$ occur in acute viral infections and from non-infectious causes $[17,20]$. Since sepsis is the most likely treatable cause of inflammation in neonates, elevation of CRP has been a useful marker for sepsis in many studies, although sensitivity and negative predictive value are not high enough for CRP alone to be a definitive diagnostic test. Normal value of CRP is $<1.6 \mathrm{mg} / \mathrm{dl}$ on day 1 and 2 and $<1.0 \mathrm{mg} / \mathrm{dl}$ thereafter. Since an elevated CRP level is always associated with pathological changes, determination of CRP is of great value in diagnosis, treatment and monitoring of inflammatory conditions. The serum CRP concentration increase faster than that of ESR and when the condition subsides, CRP falls very quickly, reaching normal levels several days before the ESR normalizes (Fig.1).

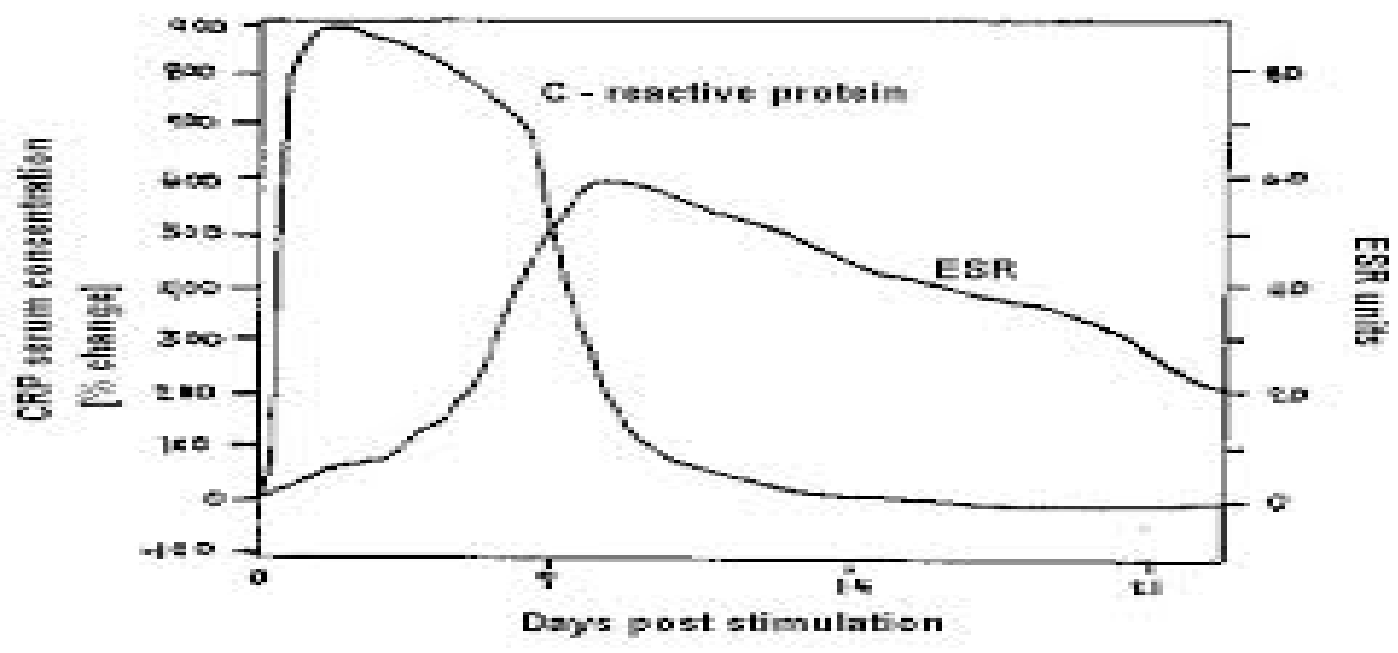

Fig. 1: CRP begins to rise in bacterial infections within 4-6hrs, peaks at 36-50 hours, closely parallels acute response with 4-7 hours half life, allowing to normal 3-7days after the stimulus is withdrawn. The ESR shows a slower rise and return to normal than C-reactive protein (CRP).

The qualitative latex agglutination test was the first laboratory method with a detection limit of approximately $10 \mathrm{mg} / \mathrm{L}$. Because CRP levels can increase so rapidly and dramatically, the latex agglutination assay is subject to false negative reaction due to a prozone type phenomenon in which all of the antibodies combining sites on the latex particles are bound to an excess of CRP so no cross-combining (agglutination) can occur. Like the qualitative test, the semi quantitative test can be performed in 15 to 30 minutes and has a reported upper detection level between 6 and $10 \mathrm{mg} / \mathrm{L}[21]$. The newer immunoassays include laser nephelometry (the most popular method), RIA, and enzyme immunoassays and have created a renewed interest in CRP testing in a variety of clinical settings. An Ultra-Sensitive immunoturbedimetric assay has been developed for CRP. The assay has sensitivity of $0.1 \mathrm{mg} / \mathrm{L}$ and results are available in minutes. 
Under this background, a study on early onset sepsis in newborn was undertaken

- To find specificity, sensitivity, positives and negative predictive values of CRP

- Relationship of risk factors with raised CRP

- Correlation of CRP and blood culture

\section{Materials and Methods}

A prospective, observational, cohort study was done in the department of Pediartrics and Obstetrics of Silchar Medical College and Hospital, Assam during a period of one year from July 2013 to June 2014. Hospital born newborns with at least 2 of risk factors like LBW, preterm, febrile illness in the mother within 2 weeks of delivery, 3 or more per vaginal examinations after rupture of membrane, foul smelling liquor, prolonged rupture of membrane, prolonged or difficult delivery or prenatal asphyxia were included. Babies born at $<28$ weeks, lethal congenital anomaly or antibiotic to the mother during labor were excluded from the study. Out of total 5960 babies born, 298(5\%) babies were selected. The study was approved by hospital ethical society. Written informed consent was taken from parents. Cord blood was collected and sent for sepsis screen including CRP, total leucocytic count(TLC), absolute neutrophil count(ANC) and band cell count(I/T ratio). CRP ( $>6 \mathrm{mg} / \mathrm{L})$, $\mathrm{TLC}(<5000 /$ cu.mm $), \operatorname{ANC}(<1500 /$ cu.mm $)$ and $\mathrm{I} / \mathrm{T}$ ratio $(>0.2)$ were regarded as abnormal. Neonates were followed for 72 hours. EOS was probable in presence of presentations like respiratory distress, lethargy etc and/or positive sepsis screen. Blood was collected, sent for sepsis screen, culture and sensitivity.

Antibiotic was started as per NICU protocol. At 24 and 48 hours, blood was collected and sent for sepsis screen and culture sensitivity in all 298 babies. CRP was measured in serum by turbedimetric immunoassay supplied commercially by Transasia Bio- Medicals Ltd. Daman, Erba Diagnostics Mannheim GmbH, Germany. The performance characteristic for CRP reagents was measured in a clinical chemistry semi-auto analyser (Erba Mannheim, Chem5x). Measuring range was 0-220 mg/L. Data was collected in pretested Performa. Statistical analysis was done using software SPSS.15. Descriptive statistical analysis was carried out. 95\% Confidence Interval was used to find the significance of study features. Risk ratio was calculated for each level of CRP in cord blood and neonatal blood. 2x3 Fisher Exact test was used to find the significance of CRP level in relationship with the incidence of Sepsis. $\mathrm{P}$ value $<0.05$ was regarded as significant.

\section{Results}

Out of 298 suspected babies, 15(5.03\%) were found with probable sepsis in presence of symptoms and/or positive sepsis screen. Of these, $66.6 \%$ were male, $53.3 \%$ were with LBW, $73.3 \%$ were term, $60 \%$ of primipara mother, $53.3 \%$ of spontaneous vaginal delivery (SVD), $46.7 \%$ with rupture of membrane(ROM) $>24$ hrs, $46.7 \%$ with $>3$ vaginal examinations(VE), 33.3\% meconium stained liquor( MSL), 26.7\% with prolonged labor, 13.3\% with maternal fever and $13.3 \%$ with foul smelling liquor(FSL). The most common clinical presentation was respiratory distress $(33.3 \%)$. Blood culture was positive in 7 (46.66\%) cases of probable sepsis.

Table-1-Distribution of cases according to cord blood and at 24 hours sepsis screen

\begin{tabular}{|c|c|c|c|c|c|}
\hline \multirow{2}{*}{ Investigations } & \multicolumn{2}{|c|}{ No. of positive cases } & \multicolumn{2}{c|}{ Percentage } \\
\cline { 3 - 6 } & & Cord blood & At 24 hrs & Cord blood & At 24 hrs \\
\hline 1 & CRP $>6 \mathrm{mg} / \mathrm{L}$ & 20 & 170 & 6.7 & 57 \\
\hline 2 & TLC $<5000 /$ cu.mm & 4 & 8 & 2.7 & 1.3 \\
\hline 3 & ANC $<1500 /$ cu.mm & 8 & 7 & 2.7 & 2.4 \\
\hline 4 & I/T ratio $>0.2$ & 7 & 8 & 2.4 & 2.7 \\
\hline
\end{tabular}

Cord blood and 24 hours blood of 298 babies show CRP more than 6mg/L in $6.7 \%$ and 57\%; TLC $<5000 / \mathrm{cu} . \mathrm{mm}$ in $2.7 \%$ and $1.3 \%$; $\mathrm{ANC}<1,500 /$ cu.mm in $2.7 \%$ and $2.4 \%$; $\mathrm{I} / \mathrm{T}$ ratio $>0.2$ in $2.4 \%$ and $2.7 \%$ respectively. 
Table-2: Shows association between CRP levels and early onset sepsis.

1a: at $24 \mathrm{hrs}$

\begin{tabular}{|c|c|c|c|c|}
\hline CRP Levels(mg/dl) & Proven Sepsis & Probable Sepsis & No sepsis & p value \\
\hline \multicolumn{7}{|c|}{ Cord blood CRP $<6$} \\
\hline$<6$ & 0 & $1(0.36 \%)$ & $119(42.8 \%)$ & 0.02 \\
\hline$\geq 6$ & $4(1.43 \%)$ & $2(0.72 \%)$ & $95(34.2 \%)$ & 0.21 \\
\hline$>12$ & $2(0.72 \%)$ & $2(0.72 \%)$ & $53(19.0 \%)$ & 0.24 \\
\hline \multicolumn{7}{|c|}{ Cord blood CRP $>6$} & $8(40 \%)$ & 0.11 \\
\hline$<6$ & 0 & 0 & $6(30 \%)$ & 0.99 \\
\hline
\end{tabular}

At $24 \mathrm{hrs}-$ proven and probable sepsis found in 7 and 8 no of babies.

- CRP $<6 \mathrm{mg} / \mathrm{L}$ was highly significant between probable and no sepsis

1b: At 48 hours

\begin{tabular}{|c|c|c|c|c|}
\hline CRP Levels(mg/d) & Proven Sepsis & Probable Sepsis & No sepsis & P value \\
\hline \multicolumn{7}{|c|}{ Cord blood $<6 \mathrm{u}$} & $179(64.4 \%)$ & 0.009 \\
\hline$<6$ & 0 & $3(1.08 \%)$ & $50(17.9 \%)$ & 0.01 \\
\hline$\geq 6$ & $5(1.79 \%)$ & $1(0.36 \%)$ & $38(13.7 \%)$ & 0.66 \\
\hline$>12$ & $1(0.36 \%)$ & $1(0.36 \%)$ & $14(70 \%)$ & 0.16 \\
\hline \multicolumn{7}{|c|}{ Cord blood $>6$} & $2(10 \%)$ & 0.50 \\
\hline
\end{tabular}

At 48 hrs- both CRP less and more than $6 \mathrm{mg} / \mathrm{L}$ showed highly significant difference between sepsis or no sepsis

Table-3: Shows the sensitivity, specificity, positive and negative predictive value of CRP estimation at 24 hours and 48 hours for diagnosis of EOS using $6 \mathrm{mg} / \mathrm{L}$ and $12 \mathrm{mg} / \mathrm{L}$ as the cut off value.

\begin{tabular}{|c|c|c|c|c|}
\hline & Sensitivity & Specificity & PPV & NPV \\
\hline \multicolumn{5}{|c|}{ At $24 \mathrm{hrs}$} \\
\hline $\mathrm{CRP} \geq 6 \mathrm{mg} / \mathrm{L}$ & $93.3 \%$ & $44.9 \%$ & $8.2 \%$ & $99.2 \%$ \\
\hline $\mathrm{CRP} \geq 12 \mathrm{mg} / \mathrm{L}$ & $40.0 \%$ & $80.6 \%$ & $9.8 \%$ & $96.2 \%$ \\
\hline \multicolumn{5}{|c|}{ At $48 \mathrm{hrs}$} \\
\hline $\mathrm{CRP} \geq 6 \mathrm{mg} / \mathrm{L}$ & $66.7 \%$ & $68.2 \%$ & $10.0 \%$ & $97.5 \%$ \\
\hline $\mathrm{CRP} \geq 12 \mathrm{mg} / \mathrm{L}$ & $20.0 \%$ & $86.6 \%$ & $7.3 \%$ & $95.3 \%$ \\
\hline
\end{tabular}

At $24 \mathrm{hrs}-\mathrm{CRP}>6 \mathrm{mg} / \mathrm{L}$ was with high sensitivity and high NPV

$>12 \mathrm{mg} / \mathrm{L}$ was high specificity and high NPV

At $48 \mathrm{hrs}-\mathrm{CRP}>6 \mathrm{mg} / \mathrm{L}$ showed high NPV

$>12 \mathrm{mg} / \mathrm{L}$ showed both high specificity and high NPV. 
Table 4: Shows the distribution of cases according to the association of risk factors with CRP levels (Antenatal)

\begin{tabular}{|c|c|c|c|c|c|c|c|}
\hline \multirow[b]{2}{*}{$\begin{array}{c}\text { Risk } \\
\text { factors }\end{array}$} & \multirow[b]{2}{*}{$\begin{array}{c}\text { Number } \\
\text { of cases } \\
\text { observed }\end{array}$} & \multicolumn{3}{|c|}{$\operatorname{CRP}(\mathrm{mg} / \mathrm{L})$} & \multicolumn{3}{|c|}{ Risk ratio $(95 \% \mathrm{CI})$} \\
\hline & & $\begin{array}{c}\text { Cord } \\
\text { Blood } \\
(\geq 6 \\
\mathrm{mg} / \mathrm{L}) \\
(\mathrm{n}=20)\end{array}$ & $\begin{array}{c}\text { Neonatal } \\
\text { Blood } \\
(\geq 6 \\
\text { mg/L) } \\
(n=109)\end{array}$ & $\begin{array}{c}\text { Neonatal } \\
\text { Blood } \\
(>12 \\
\text { mg/L) } \\
(\mathrm{n}=61)\end{array}$ & $\begin{array}{l}\text { Cord } \\
\text { Blood } \\
(\geq 6 \\
\mathrm{mg} / \mathrm{L})\end{array}$ & $\begin{array}{c}\text { Neonatal } \\
\text { Blood } \\
(\geq 6 \\
\text { mg/L) }\end{array}$ & $\begin{array}{c}\text { Neonatal } \\
\text { Blood } \\
(>12 \mathrm{mg} / \mathrm{L})\end{array}$ \\
\hline Primipara & 170 & $\begin{array}{c}6 \\
(30 \%)\end{array}$ & $\begin{array}{c}81 \\
(74.3 \%)\end{array}$ & $\begin{array}{c}25 \\
(40.9 \%)\end{array}$ & $\begin{array}{c}0.32 \\
(0.12 \text { to } 0.81)\end{array}$ & $\begin{array}{c}2.17 * \\
(1.51 \text { to } 3.13)\end{array}$ & $\begin{array}{c}0.52 \\
(0.33 \text { to } 0.82)\end{array}$ \\
\hline Male & 188 & $\begin{array}{c}7 \\
(35 \%)\end{array}$ & $\begin{array}{c}75 \\
(68.8 \%)\end{array}$ & $\begin{array}{c}40 \\
(65.6 \%)\end{array}$ & $\begin{array}{c}0.31 \\
(0.12 \text { to } 0.76)\end{array}$ & $\begin{array}{c}1.29 \\
(0.92 \text { to } 1.79)\end{array}$ & $\begin{array}{c}1.11 \\
(0.69 \text { to } 1.78)\end{array}$ \\
\hline SVD & 169 & $\begin{array}{c}3 \\
(15 \%)\end{array}$ & $\begin{array}{c}67 \\
(61.5 \%)\end{array}$ & $\begin{array}{c}28 \\
(45.9 \%)\end{array}$ & $\begin{array}{c}0.13 \\
(0.04 \text { to } 0.45)\end{array}$ & $\begin{array}{c}1.21 \\
(0.89 \text { to } 1.66)\end{array}$ & $\begin{array}{c}0.64 \\
(0.41 \text { to } 1.01)\end{array}$ \\
\hline $\begin{array}{c}\text { Gestation } \\
<37 \text { wks }\end{array}$ & 50 & $\begin{array}{c}2 \\
(10 \%)\end{array}$ & $\begin{array}{c}13 \\
(11.9 \%)\end{array}$ & $\begin{array}{c}6 \\
(9.8 \%)\end{array}$ & $\begin{array}{c}0.55 \\
(0.13 \text { to } 2.30)\end{array}$ & $\begin{array}{c}0.67 \\
(0.41 \text { to } 1.10)\end{array}$ & $\begin{array}{c}0.54 \\
(0.25 \text { to } 1.20)\end{array}$ \\
\hline
\end{tabular}

Risk ratio - > 1 - Positive association*

$$
\leq 1 \text { - No association }
$$

95\% CI with CRP >6mg/dl, show positive correlation in primi with EOS

Table 5: Shows the distribution of cases according to the association of risk factors with CRP levels (Natal)

\begin{tabular}{|c|c|c|c|c|c|c|c|}
\hline $\mathrm{ROM}<18 \mathrm{hrs}$ & 62 & $\begin{array}{c}3 \\
(15 \%)\end{array}$ & $\begin{array}{c}18 \\
(16.5 \%)\end{array}$ & $\begin{array}{c}7 \\
(10.4 \%)\end{array}$ & $\begin{array}{c}0.67 \\
(0.20 \text { to } 2.2)\end{array}$ & $\begin{array}{c}0.75 \\
(0.49 \text { to } 1.14)\end{array}$ & $\begin{array}{c}0.47 \\
(0.22 \text { to } 0.98)\end{array}$ \\
\hline ROM 18-24 hrs & 193 & $\begin{array}{c}7 \\
(35 \%)\end{array}$ & $\begin{array}{c}90 \\
(82.6 \%)\end{array}$ & $\begin{array}{c}41 \\
(67.2 \%)\end{array}$ & $\begin{array}{c}0.29 \\
(0.12 \text { to } 0.71)\end{array}$ & $\begin{array}{c}2.57 * \\
\text { (1.66 to } 3.97)\end{array}$ & $\begin{array}{c}1.11 \\
(0.69 \text { to } 1.80)\end{array}$ \\
\hline $\mathrm{ROM}>24 \mathrm{hrs}$ & 43 & $\begin{array}{c}11 \\
(55 \%)\end{array}$ & $\begin{array}{c}25 \\
(22.9 \%)\end{array}$ & $\begin{array}{c}14 \\
(22.9 \%)\end{array}$ & $\begin{array}{c}7.53 * \\
(3.31 \text { to } 17.1)\end{array}$ & $\begin{array}{c}1.76^{*} \\
(1.29 \text { to } 2.40)\end{array}$ & $\begin{array}{c}1.76^{*} \\
\text { (1.06 to } 2.91)\end{array}$ \\
\hline Prolonged labour & 91 & $\begin{array}{c}16 \\
(80 \%)\end{array}$ & $\begin{array}{c}35 \\
(32.1 \%)\end{array}$ & $\begin{array}{c}21 \\
(34.4 \%)\end{array}$ & $\begin{array}{c}9.09 * \\
\text { (3.12 to } 26.4)\end{array}$ & $\begin{array}{c}1.07 \\
(0.78 \text { to } 1.47)\end{array}$ & $\begin{array}{c}1.19 \\
(0.74 \text { to } 1.90)\end{array}$ \\
\hline Maternal fever & 30 & $\begin{array}{c}10 \\
(50 \%)\end{array}$ & $\begin{array}{c}22 \\
(20.1 \%)\end{array}$ & $\begin{array}{c}9 \\
(14.8 \%)\end{array}$ & $\begin{array}{c}8.93 * \\
(4.04 \text { to } 19.7)\end{array}$ & $\begin{array}{c}2.25^{*} \\
(1.71 \text { to } 2.97)\end{array}$ & $\begin{array}{c}1.54 \\
(0.84 \text { to } 2.81)\end{array}$ \\
\hline$>3 \mathrm{VE}$ after ROM & 143 & $\begin{array}{c}6 \\
(30 \%)\end{array}$ & $\begin{array}{c}70 \\
(64.2 \%)\end{array}$ & $\begin{array}{c}31 \\
(50.8 \%)\end{array}$ & $\begin{array}{c}0.46 \\
(0.18 \text { to } 1.17)\end{array}$ & $\begin{array}{c}2.28^{*} \\
(1.70 \text { to } 3.06)\end{array}$ & $\begin{array}{c}1.12 \\
(0.71 \text { to } 1.75)\end{array}$ \\
\hline FSL & 22 & $\begin{array}{c}3 \\
(15 \%)\end{array}$ & $\begin{array}{c}8 \\
(7.3 \%)\end{array}$ & $\begin{array}{c}1 \\
(1.6 \%)\end{array}$ & $\begin{array}{c}2.21 \\
(0.70 \text { to } 6.98)\end{array}$ & $\begin{array}{c}0.97 \\
(0.55 \text { to } 1.73)\end{array}$ & $\begin{array}{c}0.20 \\
(0.03 \text { to } 1.43)\end{array}$ \\
\hline MSL & 104 & $\begin{array}{c}4 \\
(20 \%)\end{array}$ & $\begin{array}{c}60 \\
(55.0 \%)\end{array}$ & $\begin{array}{c}15 \\
(24.6 \%)\end{array}$ & $\begin{array}{c}0.46 \\
(0.16 \text { to } 1.35)\end{array}$ & $\begin{array}{c}2.28^{*} \\
(1.70 \text { to } 3.06)\end{array}$ & $\begin{array}{c}0.60 \\
(0.35 \text { to } 1.03)\end{array}$ \\
\hline
\end{tabular}

Risk factors- ROM $>18$ hours and $>\mathbf{2 4}$ hours, prolonged labour, maternal fever, unclean vaginal examination, MSL showed positive correlation with EOS 
Table-6: Shows the correlation of sepsis screen with blood culture.

\begin{tabular}{|c|c|c|c|c|c|}
\hline $\begin{array}{l}\text { Sl. } \\
\text { No }\end{array}$ & Screening parameters & $\begin{array}{c}\text { Culture } \\
\text { positives } \\
\mathrm{n}=7 \\
(\%)\end{array}$ & $\begin{array}{c}\text { Culture } \\
\text { negative } \\
\mathrm{n}=8 \\
(\%)\end{array}$ & $\begin{array}{c}\text { Total cases } \\
\mathrm{n}=15\end{array}$ & P-value \\
\hline 1 & CRP positive & $7(100 \%)$ & $7(87.5 \%)$ & $14(93.3 \%)$ & 1.0000 \\
\hline 2 & Leucopenia $(<5000 / \mathrm{cmm})$ & $3(42.9 \%)$ & $1(12.5 \%)$ & $4(26.7 \%)$ & 0.2821 \\
\hline 3 & $\begin{array}{l}\text { Neutropenia } \\
(<1500 / \mathrm{cmm})\end{array}$ & $6(85.7 \%)$ & $1(12.5 \%)$ & $7(46.7 \%)$ & 0.0101 \\
\hline 4 & $\mathrm{I} / \mathrm{T}$ ratio $>0.2$ & $6(85.7 \%)$ & $2(25 \%)$ & $8(53.3 \%)$ & 0.0406 \\
\hline 5 & Two or more tests positive & $7(100 \%)$ & $1(12.5 \%)$ & $8(53.3 \%)$ & 0.0014 \\
\hline
\end{tabular}

CRP positivity showed no significant difference between culture positive or negative cases. Neutropenia and I/T ration showed significance. When 2 or more screening tests were positive, it was strongly significant.

\section{Discussion}

Neonatal sepsis is a serious condition. Prompt treatment is required to reduce mortality and morbidity. Clinical presentation is nonspecific hindering early diagnosis. High index of suspicion is needed for early diagnosis. In this study, utility of CRP was analyzed for diagnosis of EOS. Quantitative immunoassay is the most rapid,

Table-7: Studies on risk factors and CRP in neonatal sepsis.

\begin{tabular}{|c|c|c|c|c|c|c|c|c|c|c|}
\hline \multirow[b]{2}{*}{ 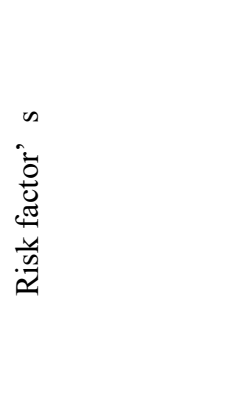 } & \multirow[b]{2}{*}{$\begin{array}{l}0 \\
0 \\
0 \\
0 \\
0 \\
0 \\
0 \\
0 \\
0 \\
0 \\
0 \\
4 \\
0 \\
\dot{0} \\
z\end{array}$} & \multicolumn{3}{|c|}{$\begin{array}{l}\text { Present Study } \\
\text { CRP (mg/dl) }\end{array}$} & \multirow[b]{2}{*}{ 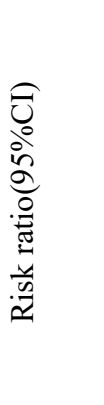 } & \multirow[b]{2}{*}{ 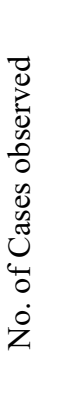 } & \multicolumn{3}{|c|}{$\begin{array}{l}\text { Mathai et al[25] } \\
\text { CRP (mg/dl) }\end{array}$} & \multirow[b]{2}{*}{ 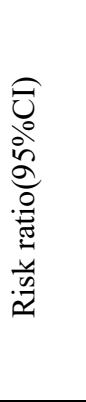 } \\
\hline & & 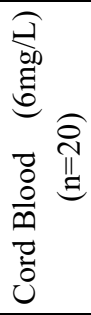 & 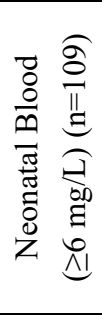 & 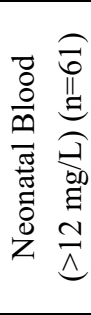 & & & 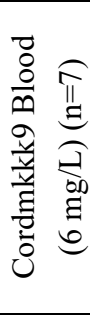 & 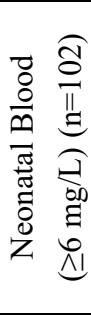 & 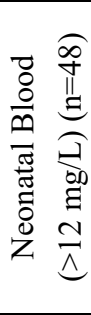 & \\
\hline Primiparity & 170 & 6 & $81 *$ & 25 & $2.17 *$ & 164 & 6 & $77^{*}$ & 32 & $* 1.62$ \\
\hline $\mathrm{ROM}<18 \mathrm{hrs}$ & 62 & 3 & 18 & 7 & & 58 & 1 & 20 & 11 & \\
\hline ROM 18-24 hrs & 193 & 7 & $90^{*}$ & 41 & $2.57 *$ & 192 & 6 & 82 & 37 & \\
\hline ROM $>24$ hrs & 43 & $11 *$ & $25^{*}$ & $14 *$ & $\begin{array}{l}7.53^{*}, \\
1.76^{*}, \\
1.76^{*}\end{array}$ & 75 & $5 *$ & 30 & 16 & $* 5.83$ \\
\hline Prolonged labour & 91 & $16^{*}$ & 35 & 21 & $9.09 *$ & 103 & $7 *$ & 47 & $26^{*}$ & $* 1.69$ \\
\hline Maternal fever & 30 & $10 *$ & $22 *$ & 9 & $\begin{array}{l}8.93^{*} \\
2.25^{*}\end{array}$ & 22 & $3 *$ & 11 & $8 *$ & $\begin{array}{l}* 7.77 \\
* 2.07\end{array}$ \\
\hline$>3 \mathrm{VE}$ after ROM & 143 & 6 & $70 *$ & 31 & $2.28 *$ & 114 & 5 & $56^{*}$ & 27 & $* 1.45$ \\
\hline FSL & 22 & 3 & 8 & 1 & & 6 & 1 & 4 & 2 & \\
\hline MSL & 104 & 4 & $60 *$ & 15 & $2.28 *$ & 50 & 2 & $28 *$ & 13 & $* 1.51$ \\
\hline $\begin{array}{l}\text { Gestation } \\
<37 \text { wks }\end{array}$ & 50 & 2 & 13 & 6 & & 32 & 1 & 9 & 4 & \\
\hline Male & 188 & 7 & 75 & 40 & & 142 & 6 & 56 & 25 & \\
\hline SVD & 169 & 3 & 67 & 28 & & 134 & 1 & 50 & 21 & \\
\hline
\end{tabular}


sophisticated and sensitive method of detecting and measuring CRP [22,23,24] . Immuno-turbidity method was used to measure CRP.

In the present study cord CRP was elevated ( $\geq 6 \mathrm{mg} / \mathrm{L})$ in 20 babies $(6.7 \%)$. The result in our study is comparable to the study done by Chiesa et al[21] which shows several intrapartum risk factors can cause elevated CRP levels in the absence of infection. Since CRP does not cross placenta, the elevated levels are due to production of CRP in the neonate.

In our study, ANC was observed in less cases as reported by Yadav et al[26]. Positive CRP was higher as observed by Mathai et al[25].

In this study, there was significant association of CRP with risk factors as observed by Mathai et al..

Table-8: studies on CRP in neonatal sepsis.

\begin{tabular}{|c|c|c|c|c|}
\hline Authors & Sensitivity & Specificity & PPV & NPV \\
\hline Mathai et al[25] & $80 \%$ & $60 \%$ & $7.7 \%$ & $98.6 \%$ \\
\hline K Swarnkar et al[27] & $52.3 \%$ & $56 \%$, & $89 \%$ & $14.3 \%$ \\
\hline Varsha et al[28] & $60 \%$ & $88.2 \%$ & $33 \%$ & $95.7 \%$ \\
\hline Twinkle N Gandhi et al[29]. & $100 \%$ & $75 \%$ & $77 \%$ & $100 \%$ \\
\hline Jan AZ et al.[30] & $88.4 \%$ & $89.1 \%$ & $90.5 \%$ & $86.7 \%$ \\
\hline Sucilathangam G. et al[31] & $50.0 \%$ & $69.4 \%$ & $38.8 \%$ & $78.1 \%$. \\
\hline Gerdes et al[32] & $70 \%-93 \%$ & $78 \%-94 \%$ & $7 \%-43 \%$ & $97-99 \%$ \\
\hline Present study & $93.3 \%$ & $44.9 \%$ & $8.2 \%$ & $99.2 \%$ \\
\hline
\end{tabular}

In the present study, we found that CRP has a high sensitivity, low specificity, low PPV and high NPV as observed by other workers (Table 6). This signifies that CRP is not of much use in diagnosing neonatal sepsis, but lower levels $(<6 \mathrm{mg} / \mathrm{l})$ are helpful in excluding sepsis (Table 2). Only elevated CRP is not significantly correlated with culture proven EOS as observed by other authors also [25, 27].

\section{Conclusion}

Our study concludes with the following comments that

1. CRP is a highly sensitive acute phase reactant

2. Perinatal risk factors may increase CRP

3. Specificity and positive predictive value of CRP are low.

4. There is no significant correlation of CRP and culture positivity

5. Combined two or more tests of sepsis screen is significantly correlated with proven sepsis and can be used for early diagnosis.

6. Absence of raised CRP can exclude sepsis

7. Isolation of organism is the gold standard for diagnosis.

Present study recommends that serum CRP $>6 \mathrm{mg} / \mathrm{dl}$ with at least another sepsis screen parameter should be used as an early marker of EOS.
Funding: Nil, Conflict of interest: None initiated, Perission from IRB: Yes

\section{Bibliography}

1. Dadhich JP, Paul VK. State of India's Newborns, National Neonatology Forum and Saving Newborn Lives. New Delhi. Save the Children (US); 2004.

2. Lawn JE, Cousens S, Zupan J. WHO estimates the causes of death in children. Lancet. 2005; 365 : 1147-1152.

3. National Neonatal Perinatal Database. Report for year 2002-2003. National Neonatology Forum. India; 2005 Jan.

4. Ralph A Franciosi, Blaise E Favara. A Single Blood Culture for Confirmation of the Diagnosis of Neonatal Septicemia. Am J Clin Pathol. 1972 Feb; 57: 215-9. 
5. Donald V Eitzman, Richard $\mathrm{T}$ Smith. The Significance of Blood Cultures in the Newborn Period. Am J Dis Child. 1957 Dec; 94: 601-3.

6. Sarff LD, Platt LH, McCracken GH Jr. Cerebrospinal fluid evaluation in neonates: comparison of high-risk infants with and without meningitis. J Pediatr. 1976 Mar;88(3):473-7.

7. Meharban singh. Care Of The Newborn. 7th Edition. Sagar Publishers; 2010. P 2-3.

8. Franz AR et al. Reduction of unnecessary antibiotic therapy in newborn infants using interleukin-8 and C-reactive protein as markers of bacterial infections. Pediatrics. 1999;104:447-453

9. Felix NS, Nakajima H, Kagan BM. Serum Creactive protein in infections during the first six months of life. Pediatrics. 1966 Feb;37(2):270-7.

10. Philipson L, Tevtaras E. C-reactive protein in infancy: Its appearance during the first year of life transplacental passage and electro phoretic pattern. Acta pediatr Scan. 1957; 46: 1

11. Tillett WS, Francis T. SEROLOGICAL REACTIONS IN PNEUMONIA WITH A NONPROTEIN SOMATIC FRACTION OF PNEUMOCOCCUS. J Exp Med. 1930 Sep 30;52(4):561-71.

12. Wood HF, McCarty M, Slater RJ. The occurrence during acute infections of a protein not present in blood: Physical chemical characteristics of the protein crystallized by a modified technique. J Exp Med. 1954; 100: 71-79.

13. Gotschlich EC, Edelman GM. C-reactive protein: a molecule composed of subunits. Proc Natl Acad Sci U S A. 1965 Aug;54(2):558-66.

14. Osmand AP, Friedenson B, Gewurz H, Painter RH, Hofmann T, Shelton E. Characterization of Creactive protein and the complement subcomponent $\mathrm{C} 1 \mathrm{t}$ as homologous proteins displaying cyclic pentameric symmetry (pentraxins). Proc Natl Acad Sci U S A. 1977 Feb;74(2):739-43.

15. Oliveira EB, Gotschlich EC, Liu TY. Primary structure of human C-reactive protein. Proc Natl Acad Sci U S A. 1977 Aug;74(8):3148-51.
16. HANSON LA, NILSSON LA. Studies on Creactive protein. 2. The presence of $\mathrm{C}$-reactive protein during the pre- and neonatal period. Acta Pathol Microbiol Scand. 1962;56:409-14.

17. Philip AG, Mills PC. Use of C-reactive protein in minimizing antibiotic exposure: experience with infants initially admitted to a well-baby nursery. Pediatrics. 2000 Jul;106(1):E4.

18. Duclos T. Function of C-reactive protein. Ann Med.2000; 32: 274-8.

19. Ballou S. Kushner I. C-reactive protein and the acute phase response. Adv Intern Med 1992; 37 : 313-6.

20. Gabay C, Kushner I. Acute-phase proteins and other systemic responses to inflammation. N Engl J Med. 1999 Feb 11;340(6):448-54.

21. Chiesa C, Signore F, Assumma M, Buffone E, Tramontozzi P, Osborn JF, Pacifico L. Serial measurements of C-reactive protein and interleukin6 in the immediate postnatal period: reference intervals and analysis of maternal and perinatal confounders. Clin Chem. 2001 Jun;47(6): 1016-22.

22. O'Callaghan $\mathrm{C}$ et al. C-reactive protein Concentrations in neonates: determination by Latex enhanced Immunoassay. J Clin Pathol. 1984; 37 : 1027-28.

23. Shine B, Gould J, Campbell C. Serum C-reactive protein in normal and infected Neonates. Clin Chim Acta. 1985; 148: 197-203.

24. Jaye DL, Waites KB. Clinical applications of Creactive protein in pediatrics. Pediatr Infect Dis J. 1997 Aug;16(8):735-46; quiz 746-7.

25. Elizabeth Mathai et al. Is C-reactive protein level useful in differentiating infected from uninfected neonates among those at risk of infection? Indian Pediatrics. 2004; 41: 895-900.

26. Yadav AK, Wilson CG, Prasad PL, Menon PK. Polymerase chain reaction in rapid diagnosis of neonatal sepsis. Indian Pediatr. 2005 Jul;42(7): 681-5. 
27. K Swarnkar, M Swarnkar. A Study Of Early Onset Neonatal Sepsis With Special Reference To Sepsis Screening Parameters In A Tertiary Care Centre Of Rural India. The Internet Journal of Infectious Diseases. 2012; Volume10 : Number 1.

28. Varsha Rusia U, Sikka M, Faridi MM, Madan N. Validity of hematologic parameters in identification of early and late onset neonatal infection. Indian $\mathrm{J}$ Pathol Microbiol. 2003 Oct;46(4):565-8.

29. Twinkle N Gandhi, Manish G Patel, Mannu R Jain, Rajeevkumar B Saxena, Pragnesh J Bhuva. Utility of c reactive protein as inflammatory marker in early diagnosis of neonatal septicaemia: a cross sectional study, national journal of medical research. 2012 Oct - Dec; Volume2 | Issue 4 |

30. Jan AZ, Gul Z, Liaqat F. Daignostic value of Creactive protein and haematological markers in neonatal sepsis. Gomal J Med Sci. 2013; 11:212-5.

31. Sucilathangam $G$ et al. Early Diagnostic Markers for Neonatal Sepsis. Journal of Clinical and Diagnostic Research. 2012 May; Vol-6(4): 627-631.

32. Gerdes JS. Diagnosis and management of bacterial infections in the neonate. Pediatr Clin North Am. 2004 Aug;51(4):939-59, viii-ix.

\section{How to cite this article?}

Devi D, Kumar R. Role of C-reactive protein in rapid diagnosis of early neonatal sepsis in a tertiary care hospital. J PediatrRes.2017;4(07):429-437.doi:10.17511/ijpr.2017.i07.01. 